\title{
"Pure" Primary Large Cell Neuroendocrine Carcinoma of the Urinary Bladder
} Mesanenin "Saf" Primer Büyük Hücreli Nöroendokrin Karsinomu

\section{Dear Editors,}

Large Cell Neuroendocrine Carcinoma (LCNC) is defined in the urinary bladder, as in other sites, as a high-grade neoplasm exhibiting neuroendocrine features at the hematoxylin and eosin level, and high mitotic activity and evidence of neuroendocrine differentiation at the immunohistochemical level. Recently we observed a case of LCNC of the bladder in a 68-year-old man. The patient presented with gross hematuria of two weeks duration in October 2011. No significant clinical history was found. Urinary cytology identified malignant cells (Figure 1). Chest radiography and computerized tomography of the abdomen and pelvis showed no evidence of other primary tumours. A contrast total body CT revealed a $3 \times 4 \mathrm{~cm}$ mass in the dome of the urinary bladder. Transurethral resection (TR) and subsequently radical cystoprostatectomy (CP) with bilateral lymphadenectomy (L) were performed in December 2012. The macroscopic examination of the CP revealed a $2.8 \times 2.2 \mathrm{~cm}$ mass situated on the dome with infiltration of muscularis propria (Figure 2). Histologically the tumour showed organoid nesting, trabecular growth, rosettes and perilobular palisading patterns, suggesting a neuroendocrine differentiation. The tumour cells were large, with moderate cytoplasm. Nucleoli were frequent and prominent. Mitotic count was 12 per $\mathrm{mm}^{2}$. Large zones of necrosis were found (Figure 3). The tumour invaded the deep muscularis propria. The 56 lymph nodes were free of disease ( $\mathrm{pT} 2 \mathrm{bN} 0)$. Immunohistochemical staining showed that the tumour neuroendocrine components were positive for cytokeratin 7 and for neuroendocrine markers such as neurone specific enolase (NSE) and CD 56. The PET TC total body revealed diffuse liver and bone metastases in April 2013. Radiotherapy (R), chemotherapy (Ch) and adjuvant $\mathrm{Ch}$ were administered.

We read with great interest Sar1 et al.s paper (1) "Large cell neuroendocrine carcinoma of urinary bladder; case presentation". The literature review of this authors is incomplete. The legend of Table I should be modified and replaced with "Published cases of pure (6 cases) or mixed (8 cases) bladder large cell neuroendocrine carcinoma". In fact Sar1 et al. included mixed tumours with the LCNC component. We examined all published pure bladder LCNC cases with exclusion of mixed neoplasms in order to establish the clinical-pathological, immunohistochemical,

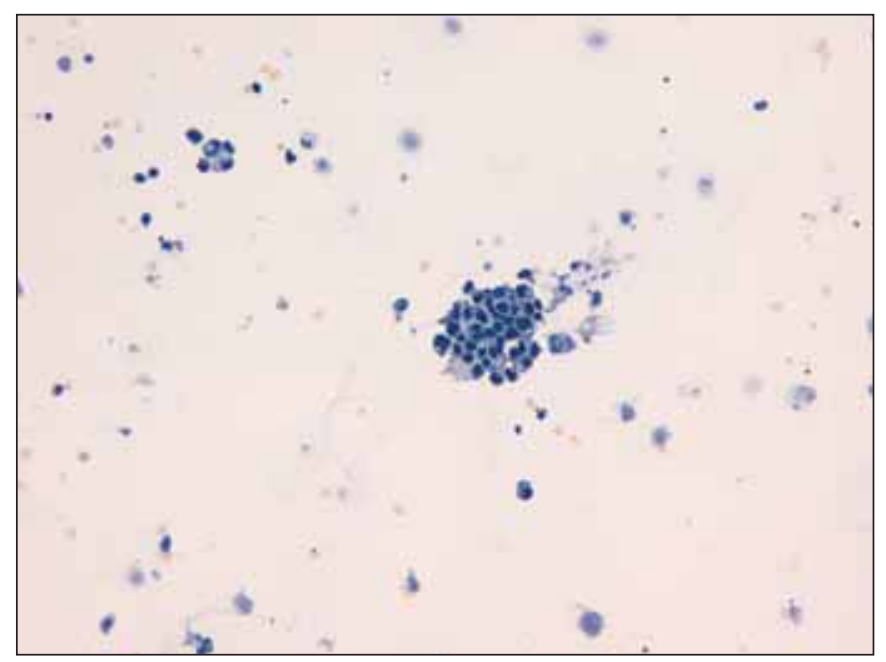

Figure 1: Urinary cytology identified malignant cells (x20 PAP).

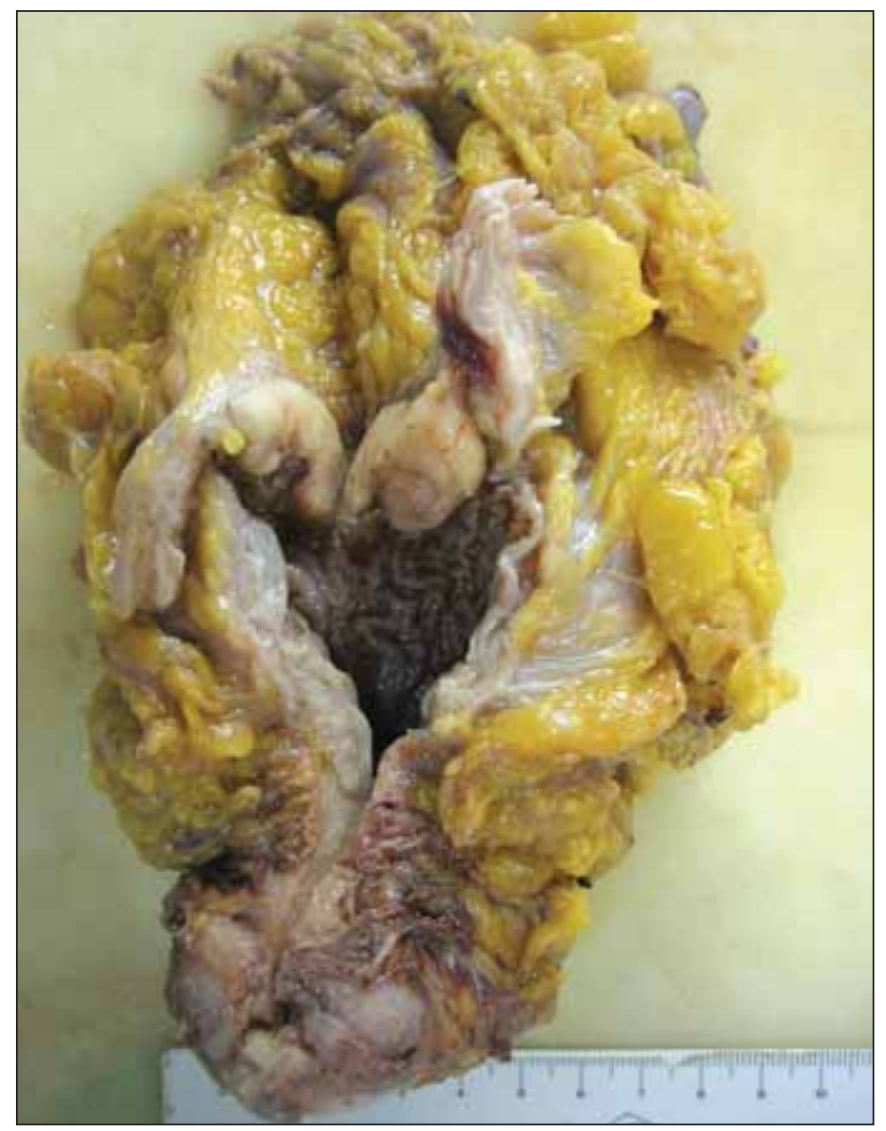

Figure 2: The macroscopic examination of the cystoprostatectomy revealed a $2.8 \times 2.2 \mathrm{~cm}$ mass situated on the dome with infiltration of muscularis propria. 


\begin{tabular}{|c|c|c|c|c|c|c|c|}
\hline 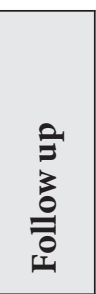 & 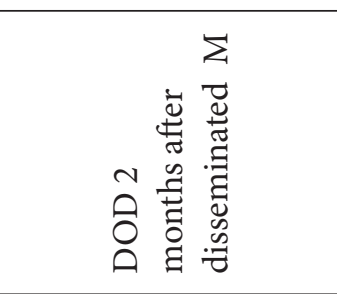 & 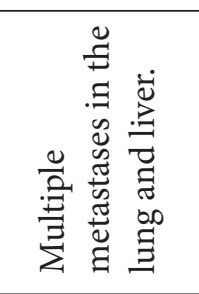 & 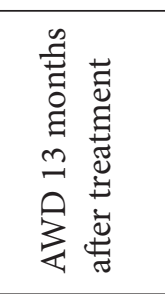 & 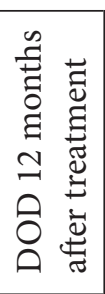 & 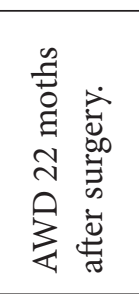 & 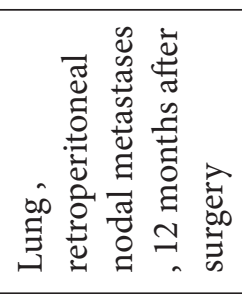 & 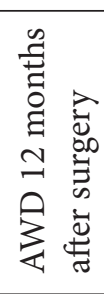 \\
\hline 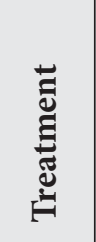 & 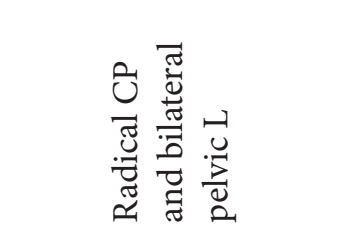 & 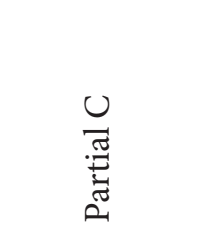 & 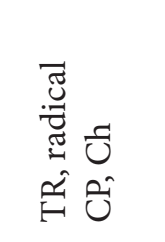 & 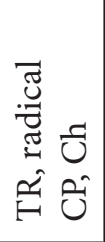 & $\begin{array}{l}\dot{0} \\
\text { 8े }\end{array}$ & 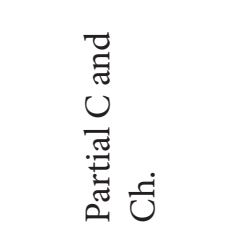 & 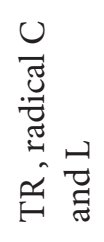 \\
\hline 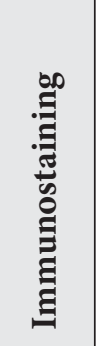 & 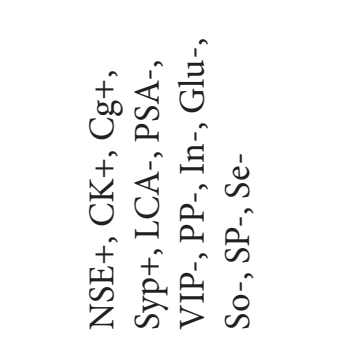 & 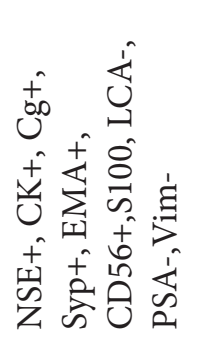 & 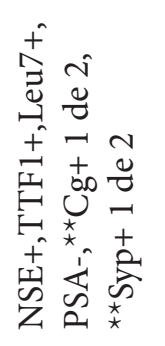 & 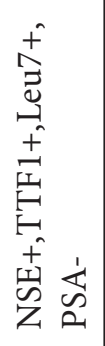 & 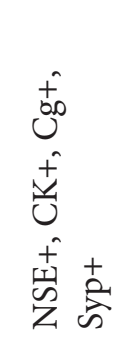 & 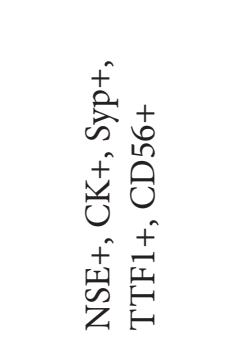 & 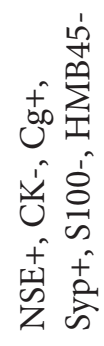 \\
\hline 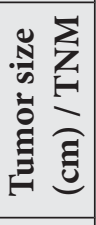 & 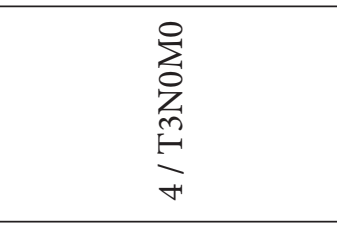 & $\begin{array}{l}\sum_{0}^{0} \\
\sum_{0}^{\infty} \\
\text { m } \\
\text { m }\end{array}$ & $\frac{\frac{n}{z}}{\frac{\tilde{z}}{z}}$ & $\frac{\tilde{z}}{z}$ & 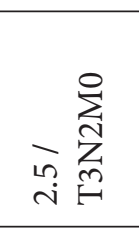 & $\frac{\text { 号 }}{\frac{\text { 亗 }}{z}}$ & 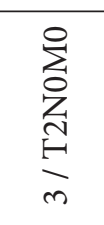 \\
\hline 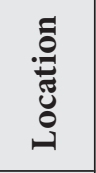 & 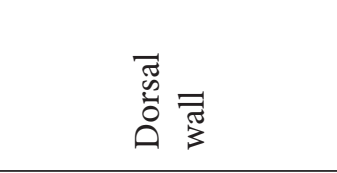 & 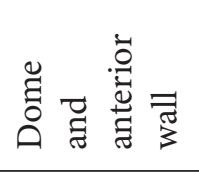 & 岂 & 艺 & 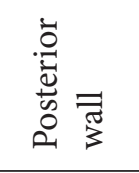 & 孚 & 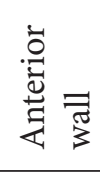 \\
\hline 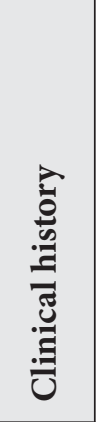 & 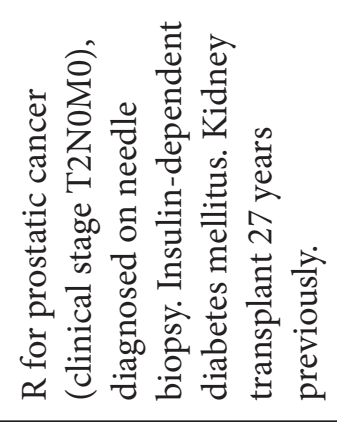 & 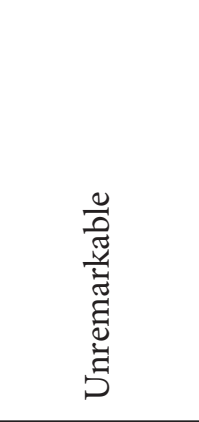 & 岂 & 岂 & 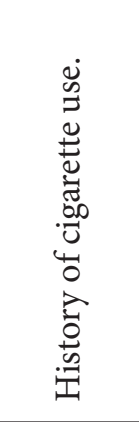 & 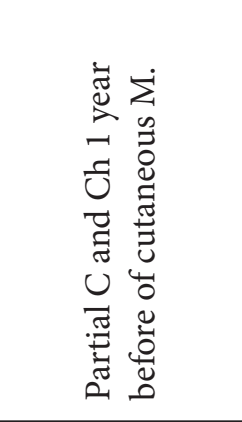 & 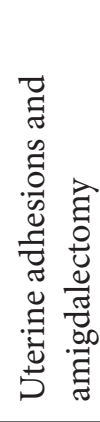 \\
\hline 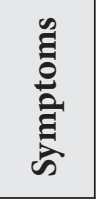 & 丰 & 応 & 孚 & 孚 & I & 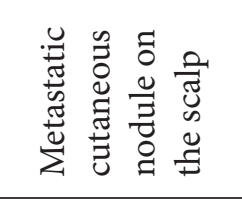 & 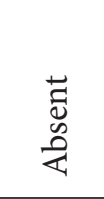 \\
\hline 总 & $\frac{\Sigma}{n}$ & $\underset{m}{\Sigma}$ & $\frac{\sum}{a}$ & $\frac{\Psi}{\not}$ & 命艺 & $\frac{\sum}{\grave{i}}$ & $\frac{\sum}{a}$ \\
\hline 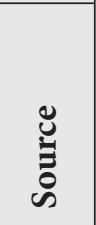 & 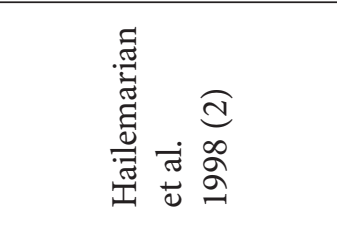 & 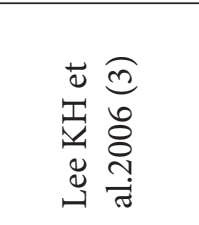 & \multicolumn{2}{|c|}{ 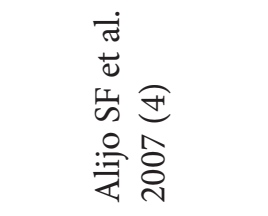 } & 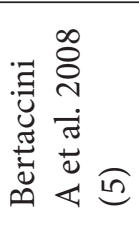 & 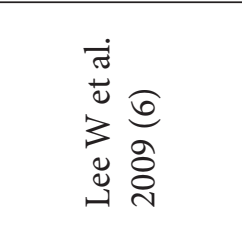 & 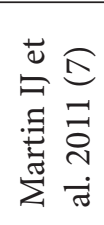 \\
\hline
\end{tabular}




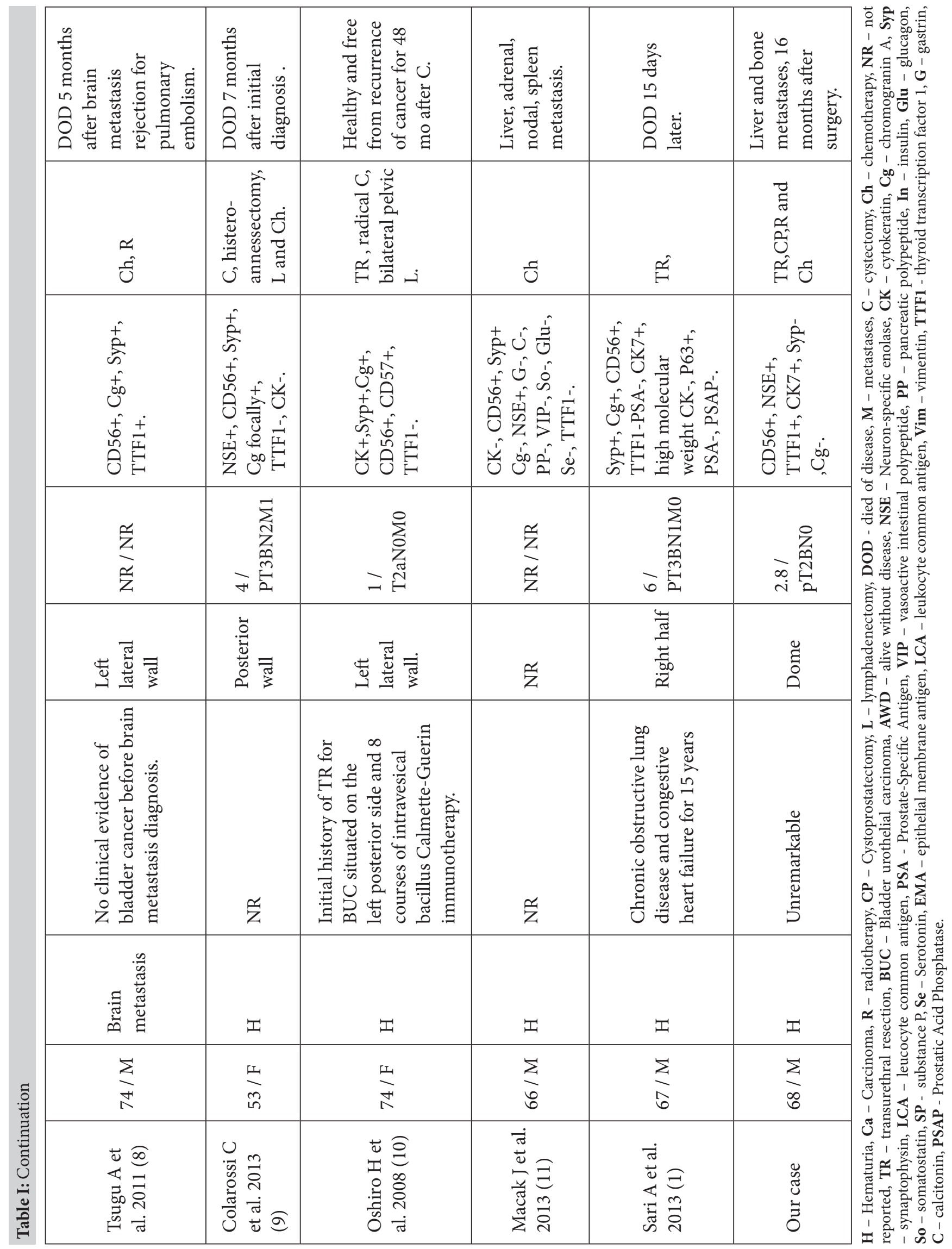




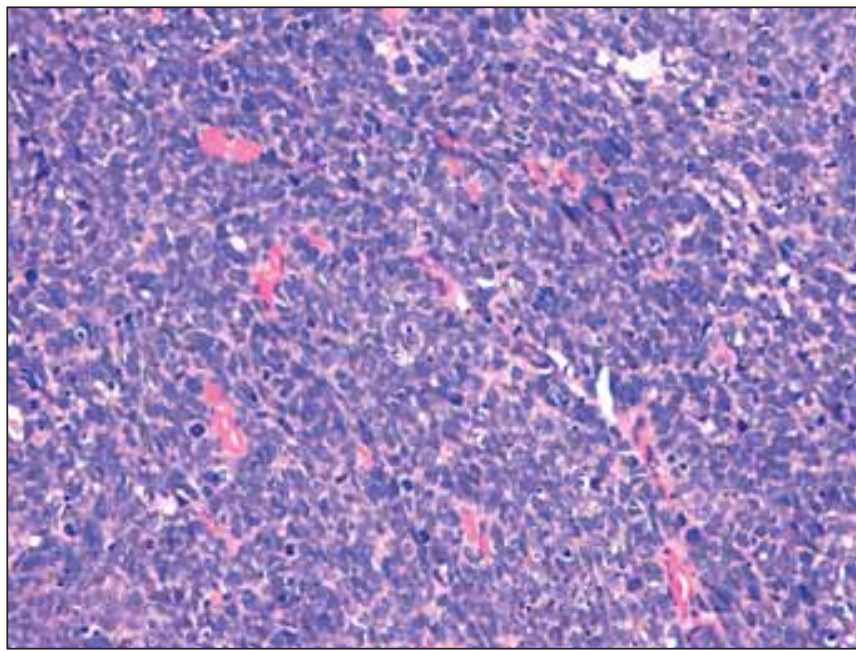

Figure 3: Histologically the tumour showed organoid nesting, trabecular growth, rosettes and perilobular palisading patterns, suggesting neuroendocrine differentiation. The tumour cells were large, with moderate cytoplasm. Nucleoli were frequent and prominent. Mitotic count was 12 per $\mathrm{mm}^{2}$ (x40 H\&E).

prognostic features of the disease (1-11). In our review we excluded the case reported by Abenoza et al. (12). These authors described a primary mixed adenocarcinomaneuroendocrine carcinoma of the urinary bladder of probable urachal origin. Neuroendocrine differentiation was confirmed by ultrastructural (neurosecretory granules) and immunohistochemical studies (chromogranin and neuronspecific enolase). Two local recurrences and multiple metastases consisted exclusively of the neuroendocrine component. The patient died 30 months after diagnosis with widely metastatic neuroendocrine carcinoma.

Evans et al. case (13) case was not considered because only less than $5 \%$ of the total tumour volume was adenocarcinoma. Dundr et al's case (14) was excluded because the tumour showed neuroendocrine markers (chromogranin A, NSE, and synaptophysin), but lymphoepithelioma-like features were found and a high-grade papillary transitional cell carcinoma was present in the overlying mucosa. The neoplasm reported by Li et al. (15) is a mixed malignancy composed of large cell neuroendocrine and mesenchymal components. Quek et al. (16) reported 25 neuroendocrine tumours of the bladder including 5 cases of LCNC of which 3 had a secondary urothelial cell carcinoma component. However, this authors did not describe the clinical-pathological, and prognostic features and these cases have therefore been excluded in present literature review. Trimeche et al. (17) described a mixed tumour composed $95 \%$ by LCNC and a high-grade urothelial invasive part (5\%). Consequently the present case has not been considered in our review of "pure" LCNC. Akamatsu et al. (18) reported a case of LCNC with the presence of squamous cell carcinoma and urothelial carcinoma. This case is a bladder mixed malignant tumour. Engles et al. (19) reported one case of bladder malignancy composed of high-grade urothelial carcinoma, small cell carcinoma and LCNBC. Hata and Tasaki (20) described LCNBC localised on the anterior wall associated with urothelial carcinoma and primary lung cancer.

In conclusion pure LCNC of the bladder is a very aggressive malignancy, unresponsive to therapy.

\section{Teresa PUSIOL}

S. Maria del Carmine Hospital, Anatomic Pathology, ROVERETO, ITALY

E-mail: teresa.pusiol@apss.tn.it

\section{Maria Grazia ZORZI}

S. Maria del Carmine Hospital, Anatomic Pathology, ROVERETO, ITALY

\section{Doriana MORICHETTI}

S. Maria del Carmine Hospital, Anatomic Pathology, ROVERETO, ITALY

\section{REFERENCES}

1. Sari A, Ermete M, Sadullahoğlu C, Bal K, Bolükbaşi A: Large cell neuroendocrine carcinoma of urinary bladder; case presentation. Turk Patoloji Derg 2013, 29:138-142

2. Hailemariam S, Gaspert A, Komminoth P, Tamboli P, Amin M: Primary, pure, large-cell neuroendocrine carcinoma of the urinary bladder. Mod Pathol 1998, 11:1016-1020

3. Lee KH, Ryu SB, Lee MC, Park CS, Juhng SW, Choi C: Primary large cell neuroendocrine carcinoma of the urinary bladder. Pathol Int 2006, 56:688-693

4. Alijo Serrano F, Sanchez-Mora N, Angel Arranz J, Hernandez C, Alvarez-Fernandez E: Large cell and small cell neuroendocrine bladder carcinoma: Immunohistochemical and outcome study in a single institution. Am J Clin Pathol 2007, 128:733-739

5. Bertaccini A, Marchiori D, Cricca A, Garofalo M, Giovannini C, Manferrari F, Gerace TG, Pernetti R, Martorana G: Neuroendocrine carcinoma of the urinary bladder: Case report and review of the literature. Anticancer Res 2008, 28(2B): 1369-1372

6. Lee WJ, Kim CH, Chang SE, Lee MW, Choi JH, Moon KC, Koh JK: Cutaneous metastasis from large-cell neuroendocrine carcinoma of the urinary bladder expressing CK20 and TTF-1. Am J Dermatopathol 2009, 31(2):166-169

7. Martín IJ, Vilar DG, Aguado JM, Perelló CG, Aliaga MR, Argente VG, Ferreres LA, Gómez JG: Large cell neuroendocrine carcinoma of the urinary bladder. Bibliographic review. Arch Esp Urol 2011, 64:105-113

8. Tsugu A, Yoshiyama M, Matsumae M: Brain metastasis from large cell neuroendocrine carcinoma of the urinary bladder. Surg Neurol Int 2011, 2:84 
9. Colarossi C, Pino P, Giuffrida D, Aiello E, Costanzo R, Martinetti $D$, Memeo L: Large cell neuroendocrine carcinoma (LCNEC) of the urinary bladder: A case report. Diagn Patho 2013, 8:19

10. Oshiro H, Odagaki Y, Iobe H, Ozu C, Takizawa I, Nagai T, Matsubayashi J, Inagaki A, Miyake S, Nagao T: Primary large cell neuroendocrine carcinoma of the ureter. Int J Clin Exp Pathol 2013, 6:729-736

11. Mačák J, Dundr P, Dvořáčková J, Buzrla P, Němec D: Primary large cell neuroendocrine carcinoma of the urinary bladder. Cesk Patol 2013, 49:80-83

12. Abenoza P, Manivel C, Sibley RK: Adenocarcinoma with neuroendocrine differentiation of the urinary bladder. Clinicopathologic, immunohistochemical, and ultrastructural study. Arch Pathol Lab Med 1986, 110:1062-1066

13. Evans AJ, Al-Maghrabi J, Tsihlias J, Lajoie G, Sweet JM, Chapman WB: Primary large cell neuroendocrine carcinoma of the urinary bladder. Arch Pathol Lab Med 2002, 126:1229-1232

14. Dundr P, Pesl M, Povysil C, Vitkova I, Dvoracek J: Large cell neuroendocrine carcinoma of the urinary bladder with lymphoepithelioma-like features. Pathol Res Pract 2003, 199: 559-563

15. Li Y, Outman JE, Mathur SC: Carcinosarcoma with a large cell neuroendocrine epithelial component: First report of an unusual biphasic tumour of the urinary bladder. J Clin Pathol 2004, 57:318-320

16. Quek ML, Nichols PW, Yamzon J, Daneshmand S, Miranda G, Cai J, Groshen S, Stein JP, Skinner DG: Radical cystectomy for primary neuroendocrine tumors of the bladder: The University of Southern California experience. J Urol 2005, 174:93-96

17. Trimeche M, Mutijima E, Ziadi S, Mestiri S, Sorba NB, Sriha B, Mosbah AT, Korbi S: Carcinome neuro-endocrine à grandes cellule primitive de la vessie. Prog Urol 2006, 16:610-612

18. Akamatsu S, Kanamaru S, Ishihara M, Sano T, Soeda A, Hashimoto K: Primary large cell neuroendocrine carcinoma of the urinary bladder. Int J Urol 2008, 15:1080-1083

19. Engles CD, Slobodov G, Buethe DD, Lightfoot S, Culkin DJ: Primary mixed neuroendocrine carcinoma of the bladder with large cell component: A case report and review of the literature. Int Urol Nephrol 2012, 44:1021-1025

20. Hata S, Tasaki Y: A case of the large cell neuroendocrine carcinoma of the urinary bladder. Case Rep Med 2013, Article ID 804136

\section{Author's Reply:}

We thank the author for his interest and valuable comments on our recent publication (1). In our article, we investigated all the English literature to the best of our knowledge, and summarized all the reported cases of large cell neuroendocrine carcinoma of the urinary bladder in one table.

Our paper has been accepted for publication in the Turkish Journal of Pathology on April 20, 2011 and published in the 2 nd issue (May) of 2013, which is approximately 2 years after the acceptance date. Therefore newly published cases of large cell neuroendocrine carcinoma (LCNEC) of the bladder in this time period of two years did not appear on the review table of our article. However after careful investigation of the English literature, we noticed that articles published by Bertaccini A et al. (2) in 2008 and Lee $\mathrm{W}$ et al. (3) in 2009 were not presented in our table.

We preferred to include and specify both pure and mixed forms of this tumor in our table in order to better understand the behaviour of this very rare tumor as many of these cases were reported to have mixed histology.

Yours sincerely

\section{Ayşegül SARI}

İzmir Atatürk Eğitim ve Araştırma Hastanesi, Katip Çelebi Üniversitesi, Tıp Fakültesi, Patoloji Bölümü, IZMiR, TURKEY

E-mail: aysegulakder@gmail.com

\section{REFERENCES}

1. Sari A, Ermete M, Sadullahoğlu C, Bal K, Bolükbaşi A: Large cell neuroendocrine carcinoma of urinary bladder; case presentation. Turk Patoloji Derg 2013, 29:138-142

2. Bertaccini A, Marchiori D, Cricca A, Garofalo M, Giovannini C, Manferrari F, Gerace TG, Pernetti R, Martorana G: Neuroendocrine carcinoma of the urinary bladder: Case report and review of the literature. Anticancer Res 2008, 28(2B): $1369-1372$

3. Lee WJ, Kim CH, Chang SE, Lee MW, Choi JH, Moon KC, Koh JK: Cutaneous metastasis from large-cell neuroendocrine carcinoma of the urinary bladder expressing CK20 and TTF-1. Am J Dermatopathol 2009, 31:166-169 